\title{
Pleasure and Suffering in Intensive Care Unit Nursing Staff
}

\author{
Helena Eri Shimizu ${ }^{1}$ \\ Djalma Ticiani Couto \\ Edgar Merchan-Hamann ${ }^{3}$
}

The aim of this study was to analyze the causal factors of pleasure and suffering in Intensive Care Unit (ICU) nursing staff and to compare the occurrence of these factors at the beginning and end of the career. This was a cross-sectional descriptive study conducted with 26 nurses and 96 nursing technicians. The previously validated Pleasure and Suffering Scale was used. The data were analyzed using descriptive statistics with the SPSS 12.0 software and the Kruskal Wallis test was used to assess the presence of these factors at the beginning and end of the career. The results indicated that, for both the nurses and the nursing technicians, the factors that contribute to feelings of pleasure, professional achievement and freedom of expression, and the factors that cause suffering, professional exhaustion and lack of recognition, were encountered at critical levels.

Descriptors: Nurses; Intensive Care Units; Occupational Health.

\footnotetext{
${ }^{1}$ RN, Ph.D. in Nursing. Associate Professor, Universidade de Brasília, DF, Brazil. E-mail: shimizu@unb.br.

${ }^{2}$ RN, Secretaria de Saúde do Distrito Federal, Brasília, DF, Brazil. E-mail: djalmaacvoltara@yahoo.com.br.

${ }^{3}$ Physician, Ph.D. in Public Health. Adjunct Professor, Universidade de Brasília, DF, Brazil. E-mail: hamann@unb.br.
}

Corresponding Author:

Helena Eri Shimizu

Rua SQN 205 Bloco G Apto 605

Bairro: Asa Norte

CEP: 70843-070 Brasília, DF, Brasil

E-mail: shimizu@unb.br 


\section{Prazer e sofrimento em trabalhadores de enfermagem de Unidade de Terapia Intensiva}

O objetivo do estudo foi analisar os fatores causadores de prazer e sofrimento em trabalhadores de enfermagem que atuam em unidade de terapia intensiva (UTI) e comparar a ocorrência desses fatores, no início e no final da carreira. Este é um estudo descritivo transversal, realizado com 26 enfermeiros e 96 técnicos de enfermagem. Utilizou-se a escala de prazer e sofrimento, validada previamente. Os dados foram analisados por meio da estatística descritiva, com software SPSS12.0, e, para avaliar a presença desses fatores, no início e no final da carreira, o teste de Kruskal Wallis. Constatou-se que, tanto para enfermeiros como para os técnicos de enfermagem, os fatores que contribuem para os sentimentos de prazer, realização profissional e liberdade de expressão e os fatores que causam sofrimento, esgotamento profissional e falta de reconhecimento se encontram em níveis críticos.

Descritores: Enfermeiros; Unidade de Terapia Intensiva; Saúde do Trabalhador.

\section{Placer y sufrimiento en trabajadores de enfermería de una Unidad de Terapia Intensiva}

El objetivo del estudio fue analizar los factores causadores de placer y sufrimiento en trabajadores de enfermería que actúan en una Unidad de Terapia Intensiva (UTI) y comparar la ocurrencia de esos factores en el inicio y al final de la carrera. Se trata de un estudio descriptivo transversal, realizado con 26 enfermeros y 96 técnicos de enfermería. Se utilizó la Escala de Placer y Sufrimiento, validada previamente. Los datos fueron analizados por medio de la estadística descriptiva, con software SPSS12.0, y, para evaluar la presencia de esos factores en el inicio y al final de la carrera, se utilizó la prueba de Kruskal Wallis. Se constató que, tanto para enfermeros como para los técnicos de enfermería, los factores que contribuyen para los sentimientos de placer, realización profesional y libertad de expresión y los factores que causan sufrimiento, agotamiento profesional y falta de reconocimiento, se encuentran en niveles críticos.

Descriptores: Enfermeros; Unidade de Terapia Intensiva; Salud Laboral.

\section{Introduction}

The recognition is growing that health care workers, especially those of the nursing team, experience stressful situations in the work that lead to suffering. Several studies have indicated the need to identify, in critical areas such as the ICU, the causative factors of the suffering, as well as the defensive strategies to avoid this, in order to maintain the psycho-emotional balance of the worker ${ }^{(1-5)}$. Care for critically ill patients requires from the nurses and nursing technicians, hereafter referred to as the nursing team, speed in decision making, a heightened sense of responsibility in the prioritization of actions, the resolution of complex problems, the continuous reorganization of the activities due to frequent interruptions, and the management of a large and variable amount of information due to the diverse interventions required(1-5). Furthermore, the nursing team are almost constantly confronted with suffering and death of their fellows, and are exposed to the ambiguous feelings that are transferred to them by both the patient and their family members ${ }^{(1-2)}$. These situations invariably provoke feelings of intense anxiety, which contribute to the development of mediation strategies that function to try to avoid tensions which cumulatively threaten the integrity of their health with the risk of evolving into a framework of pathogenesis(1-3). 
The work carried out by the nursing team in this environment, although essential, has little social recognition; is undervalued and invisible to the other health professionals and the patients ${ }^{(1-2,6)}$. Additionally, in recent years in Brazil, mainly in the public health institutions, nursing care in general has been penalized with a deficiency of human and material resources that directly influences the quality of care provided to the population $^{(1-2)}$. It appears that the experience of suffering in the work in an ICU would be intense due to the constant exposure of the workers to extremely stressful situations, which are often unconsciously, characterized, according to the psychodynamics of the work $^{(7)}$, as individual or shared experiences, which have their origins in situations of conflict between the desire/needs of the employee and the organization of the work ${ }^{(7)}$. Distress in the work is manifested as a form of emotional, physical and social exhaustion, and when this is pronounced it may cause the impoverishment of the personality, leading the individual to an emotional numbness, i.e. an "erasure" of emotional manifestations(7-8). Such experiences also cause the failure of the professional if confronted with their own feelings, which may lead them to conceal from themselves the psychic suffering, their painful emotional experiences ${ }^{(9)}$.

Despite the possible health injuries arising from the organizational context, the positive significance of the work is being rediscovered as a means of preventing and overcoming these negative effects, through a position that emphasizes the positive subjective experiences in improving the quality of life of the workers and preventing pathologies $^{(9-13)}$. These work experiences, when positive, help to enrich the identity of the individual, leading to the maximum development of their potential. From this perspective, the process of caring for critically ill patients, which involves a meeting between the subjects - who care and who are cared for, due to its dynamism and complexity, demands choices, arbitrations, prioritization of actions and goals, and guidance in the decision making of the workers, which makes it somewhat possible to overcome the fragmentation of the work process. The workers can appropriate the management of their work ${ }^{(10-}$ 11) by means of permanent negotiations between what is prescribed, i.e. the standards, routines, procedures and unexpected demands of the care quotidian. It is possible to discover a new way to develop the work that is more rewarding for the workers and provides higher quality care for the patients. It is important to investigate whether there are differences in the factors associated with pleasure and with suffering at the beginning and the end of the career, to develop management strategies that foster improvement in the work processes in order to contribute to a more satisfying working life.

This study aims to analyze the factors that cause pleasure and suffering in the work of nurses and nursing technicians in the ICU, and to compare the degree of occurrence of these factors at the beginning and end of the career.

\section{Methods}

This was a cross-sectional descriptive study conducted with nurses and nursing technicians of the ICU of a tertiary public hospital, prominent within the network of the Department of State and Health, the Federal District Base Hospital. The sample was selected in a nonprobabilistic way and consisted of 122 participants who were divided into two categories: the first composed of Nurses $(n=26)$, and the second of Nursing Technicians $(n=96)$. The inclusion criterion adopted was for workers to have more than 6 months of work and those who were absent from work for more than 90 consecutive days in the ICU studied were excluded. For the data collection, a questionnaire was used to characterize the study population which included: marital status, level of schooling, number of jobs, and the Pleasure-Suffering at Work Scale (PSWS). This scale includes a Work and Risk of Illness Inventory (WRII), constructed based on the Psychodynamics of Work theoretical framework, comprising a total of four independent scales, and is an auxiliary diagnostic instrument of critical indicators in the work, having previously been validated(14).

The PSWS consists of four factors, two for joy and two for suffering. The factors that are indicators of pleasure are: professional achievement and freedom of expression; and the factors that are indicators of suffering are professional exhaustion and lack of recognition. The first factor, professional achievement, consists of nine items, with an alpha $=0.89$, and relates to the experience of professional gratification, pride and identification with the work performed. Factor two, freedom of expression, with five items, and an alpha $=0.69$, relates to the experiences of freedom to think, organize and talk about their work. Factor three, professional exhaustion, contains six items, with an alpha $=0.84$, related to frustration, insecurity, worthlessness and disqualification concerning performance expectations, producing exhaustion, distress and stress. Factor four, lack of recognition, with five items and an alpha $=0.70$, refers to experiences of injustice, indignation and devaluation 
due to non-recognition of their work. It is a Likert type scale containing five points, and aims to evaluate the occurrence, in the past six months, of the experience of feelings of pleasure and suffering in the work. In this scale, a value between 1 and 5 points is assigned, where the value of 1 conforms to nothing present, and 5 to totally present. In the PSWS, for evaluation of the factor pleasure, constituted by the factors professional achievement and freedom of expression, the parameters are as follows: above 3.7 = satisfactory evaluation; 2.3 to $3.7=$ critical evaluation; 1.0 to $2.3=$ severe evaluation. For the evaluation of the factor suffering, composed of the factors professional exhaustion and lack of recognition the following parameters are considered: 1.0 to 2.3 = satisfactory evaluation; 2.3 to $3.7=$ critical evaluation; above 3.7 = severe evaluation.

The collected data were analyzed with the aid of the software Statistical Package for the Social Sciences for Windows (SPSS) version 12.0. They were later transferred to Microsoft Excel Office XP so that the data could be formatted. Descriptive statistics were used to calculate measures of central tendency and dispersion and the frequency distribution of the demographic data. The Kruskal Wallis nonparametric test was also used to analyze the data, based on the medians of the values, in order to test the null hypothesis, which assumes equality of the populations. The test evaluated, in the PSWS, whether there were differences in professional achievement, freedom of expression, professional exhaustion and lack of recognition. The items were classified into positions or ranks for the calculation of significance, where $p<0.05$ was considered. These factors were verified among the nurses and nursing technicians at the beginning of their careers in comparison with the professionals who were at the end of their careers, in their respective categories. To perform this test, the study universe was reduced from 122 to 94 people, i.e. $77 \%$ of the initial participants, given the restriction that, up to 7 years of work was considered as the initiation of the career and more than 15 years as the end of the career, which excluded 28 workers in the intermediate phase ( 7 to 15 years in the career).

\section{Ethical issues related to the study}

The research project was approved by the Research Ethics Committee of the Health Department of the Federal District, under process No. 183/05. Subsequently, all the participants signed the Terms of Free Prior Informed Consent, conforming to Resolution No. 196/96 of the Ministry of Health

\section{Results}

\section{Characterization of the study population}

Regarding the profile of the study subjects, there was a strong participation of women (76.9\% among the nurses, and $84.4 \%$ among the technicians), confirming the same trend in other areas of nursing work. With regard to marital status, the predominance was observed of married workers in both categories: $53.8 \%$ and $53.1 \%$, for the nurses and technicians respectively. In relation to the level of schooling, it was found that among the nurses postgraduates predominated (80.8\%), while among the nursing technicians complete high school predominated $(54.3 \%)$ - the minimum level required for the performance of these duties. However, in this group, it is worth noting the significant participation of workers with tertiary or post-graduate education, $37.3 \%$. Concerning the number of jobs, $65.4 \%$ of the nurses had two or three jobs, i.e. they have a heavy work load; among the nursing technicians, the majority had only one job: $60.4 \%$.

As shown in Table 1 that follows, it was found that the factors that contribute to feelings of pleasure, expressed in "professional achievement" and "freedom of expression", were encountered at critical levels for both the nurses and the nursing technicians. The factors that contribute to the experience of suffering in the work, "professional exhaustion" and "lack of recognition", were also found at critical levels. It is worth noting that it was found that the nursing technicians expressed themselves to be slightly more exposed than the nurses to "professional exhaustion" and "lack of recognition" in relation to the work they develop.

Table 1 - Factors for evaluation of suffering and pleasure in ICU nurses and nursing technicians (Brasilia, Brazil, 2009)

\begin{tabular}{|c|c|c|c|c|c|c|c|c|c|c|c|c|}
\hline \multirow{2}{*}{ Studied category } & \multicolumn{4}{|c|}{ Nurses } & \multicolumn{4}{|c|}{ Nursing technicians } & \multicolumn{4}{|c|}{ Total } \\
\hline & $\mathbf{n}$ & Md & $\mathbf{M}$ & SD & $\mathbf{n}$ & Md & $\mathbf{M}$ & SD & $\mathbf{n}$ & Md & $\mathbf{M}$ & SD \\
\hline Professional Achievement & 26 & 3.2 & 3.2 & 0.8 & 96 & 3.1 & 3.2 & 0.9 & 122 & 3.1 & 3.2 & 0.9 \\
\hline Freedom of Expression & 26 & 3.6 & 3.6 & 0.7 & 96 & 3.6 & 3.6 & 0.7 & 122 & 3.6 & 3.6 & 0.7 \\
\hline Professional Exhaustion & 26 & 3.5 & 3.2 & 0.9 & 96 & 2.8 & 2.8 & 0.9 & 122 & 2.8 & 2.9 & 0.9 \\
\hline Lack of recognition & 26 & 3.2 & 3.0 & 0.7 & 96 & 2.6 & 2.6 & 0.8 & 122 & 2.6 & 2.7 & 0.8 \\
\hline
\end{tabular}

$\mathrm{n}=$ absolute frequency; $\mathrm{M}=$ Mean; $\mathrm{Md}=$ Median; and SD = Standard Deviation. 
Regarding the feelings of pleasure, Table 2 shows the factors that contribute to the experience of professional achievement. It was verified that two factors, "identification with the tasks that are performed" and "professional achievement" were at satisfactory levels for both professional categories. However, the feelings of "pride, satisfaction, well-being, pleasure, and motivation", were found at levels considered critical. There were differences in the perception of the factors of "recognition" and "professional valorization" between the two categories: while the nursing technicians felt less recognized than the nurses (median $=2.0$, considered a severe evaluation), the nurses felt less valued than the technicians (median $=2.0$, a severe evaluation).

Table 2 - Evaluation of the factor professional achievement in ICU nurses and nursing technicians (Brasilia, Brazil, 2009)

\begin{tabular}{|c|c|c|c|c|c|c|}
\hline \multirow{2}{*}{ Professional Achievement } & \multicolumn{3}{|c|}{ Nurses } & \multicolumn{3}{|c|}{ Nursing technicians } \\
\hline & $\mathbf{M}$ & Md & SD & $\mathbf{M}$ & Md & SD \\
\hline Identification with the tasks performed & 4.0 & 4.5 & 1.3 & 4.1 & 4.0 & 1.0 \\
\hline Professional achievement & 3.6 & 4.0 & 1.1 & 3.6 & 4.0 & 1.2 \\
\hline Pride & 3.4 & 3.0 & 0.9 & 3.3 & 3.0 & 1.2 \\
\hline Satisfaction & 3.2 & 3.0 & 0.9 & 3.1 & 3.0 & 1.1 \\
\hline Well-being & 3.1 & 3.0 & 0.9 & 3.2 & 3.0 & 1.1 \\
\hline Pleasure & 3.1 & 3.0 & 1.1 & 3.2 & 3.0 & 1.1 \\
\hline Motivation & 2.9 & 3.0 & 1.1 & 2.6 & 3.0 & 1.2 \\
\hline Recognition & 2.7 & 3.0 & 1.1 & 2.3 & 2.0 & 1.1 \\
\hline Valorization & 2.5 & 2.0 & 0.9 & 2.5 & 3.0 & 1.2 \\
\hline
\end{tabular}

$M=$ Mean; Md = Median; and SD = Standard Deviation

With regard to freedom of expression in the work, it can be observed from the data obtained (Table 3) for both categories, that the factors "solidarity with colleagues", "freedom to talk about the work with colleagues" and "freedom to use a personal style" reached levels considered satisfactory. However, the factors "freedom to speak openly at work" and "trust in colleagues" were found at levels considered critical for both categories.

Table 3 - Evaluation of the factor freedom of expression in ICU nurses and nursing technicians (Brasilia, Brazil, 2009)

\begin{tabular}{|c|c|c|c|c|c|c|}
\hline \multirow{2}{*}{ Freedom of expression } & \multicolumn{3}{|c|}{ Nurses } & \multicolumn{3}{|c|}{ Nursing technicians } \\
\hline & $\mathbf{M}$ & Md & SD & M & Md & SD \\
\hline Solidarity with colleagues & 3.9 & 4.0 & 0.9 & 4.0 & 4.0 & 0.9 \\
\hline Freedom to talk about the work with colleagues & 3.8 & 4.0 & 1.1 & 3.9 & 4.0 & 1.0 \\
\hline Freedom to use a personal style & 3.7 & 4.0 & 0.8 & 3.5 & 4.0 & 1.3 \\
\hline Freedom to speak openly at work & 3.1 & 3.0 & 1.0 & 3.2 & 3.0 & 1.1 \\
\hline Trust in colleagues & 3.0 & 3.0 & 1.0 & 3.0 & 3.0 & 1.0 \\
\hline
\end{tabular}

M = Mean; Md = Median; and SD = Standard Deviation

In the factor "professional exhaustion" (Table 4), it can be seen that the results indicate that the factors "stress, distress and frustration" are at levels considered severe for the nurses and at critical levels for the nursing technicians. The factors "dissatisfaction" and "emotional exhaustion" were evaluated at critical levels for the two categories. The factor of "insecurity" was encountered at a critical level only for the nurses.
Table 4 - Evaluation of the factor professional exhaustion in ICU nurses and nursing technicians (Brasilia, Brazil, 2009)

\begin{tabular}{|c|c|c|c|c|c|c|}
\hline \multirow{2}{*}{$\begin{array}{c}\text { Professional } \\
\text { exhaustion }\end{array}$} & \multicolumn{3}{|c|}{ Nurses } & \multicolumn{3}{|c|}{$\begin{array}{c}\text { Nursing } \\
\text { technicians }\end{array}$} \\
\hline & M & Md & SD & M & Md & SD \\
\hline Stress & 3.6 & 4.0 & 1.1 & 3.0 & 3.0 & 1.2 \\
\hline Distress & 3.5 & 4.0 & 1.0 & 3.2 & 3.0 & 1.1 \\
\hline Dissatisfaction & 3.3 & 3.0 & 0.9 & 3.0 & 3.0 & 1.1 \\
\hline Emotional exhaustion & 3.3 & 3.5 & 1.1 & 2.7 & 3.0 & 1.2 \\
\hline Frustration & 3.1 & 4.0 & 1.2 & 2.8 & 3.0 & 1.2 \\
\hline Insecurity & 2.3 & 3.0 & 0.8 & 2.0 & 2.0 & 1.0 \\
\hline
\end{tabular}

M = Mean; Md = Median; and SD = Standard Deviation. 
Concerning the evaluation of the lack of recognition (Table 5), the results indicate that the factors "indignation" and "injustice" were classified at severe level for the nurses, and critical for the nursing technicians. The factor "devalorization" was found at critical levels for both categories. However, the feelings of worthlessness and disqualification were at satisfactory levels for both categories.

Table 5 - Evaluation of the factor lack of recognition in ICU nurses and nursing technicians (Brasilia, Brazil, 2009)

\begin{tabular}{lccccccc}
\hline \multirow{2}{*}{ Lack of recognition } & \multicolumn{3}{c}{ Nurses } & & \multicolumn{3}{c}{ Nursing technicians } \\
\cline { 2 - 3 } \cline { 8 - 9 } & $\mathbf{M}$ & $\mathbf{M d}$ & $\mathbf{S D}$ & & $\mathbf{M}$ & $\mathbf{M d}$ & SD \\
\hline Indignation & 3.8 & 4.0 & 1.0 & & 3.0 & 3.0 & 1.3 \\
Injustice & 3.6 & 4.0 & 1.0 & & 3.2 & 3.0 & 1.1 \\
Devalorization & 3.2 & 3.0 & 1.0 & & 2.8 & 3.0 & 1.3 \\
Worthlessness & 2.0 & 2.0 & 0.9 & & 1.8 & 1.5 & 1.0 \\
Disqualification & 1.9 & 2.0 & 0.9 & & 1.9 & 2.0 & 1.0 \\
\hline
\end{tabular}

M = Mean; $M d=$ Median; and SD = Standard Deviation.

Analyzing the results of the PSWS regarding the possible differences between feelings of pleasure and suffering at the beginning and end of the career, it was found that the "professional achievement" in 21 nurses had a slight increase (ranking 10.0 early in the career, and 12.8 at the end) This difference was not significant $(p=0.20)$. Among the 73 nursing technicians there was also an increase which was not significant from a statistical viewpoint (ranking 35.4 early in the career, and 40.1 at the end, $p$ value $=0.21$ ). Regarding "freedom of expression", there was a significant increase among the 21 nurses when comparing the beginning and end of the career (ranking 8.3 early in the career, and 16.3 at the end, $p$ value $=0.01$ ). Among the nursing technicians, the slight increase observed was not significant (ranking 36.3 early in the career, and 38.3 at the end, $p$ value $=0.34$ ). Regarding "professional exhaustion", the slight decrease observed among the nurses was not significant (ranking 11.1 early in the career and 10.7 at the end, $p$ value $=0.48)$. In contrast, there was a significant difference among the nursing technicians (ranking 40.6 early in the career, and 29.4 at the end, $p$ value $=0.02$ ). In relation to the "lack of recognition", there was no significant differences in the observed decreases, both among the nurses (ranking 11.2 early in the career and 10.5 at the end, $p$ value $=0.52$ ), and among the nursing technicians (ranking 38.4 early in the career; and 34.0 at the end, $p$ value $=0.23$ )

\section{Discussion}

The study results demonstrated that in the perception of both the nurses and the nursing technicians, the causal factors of feelings of pleasure, professional achievement and freedom of expression, as well as the causal factors of suffering in the work, professional exhaustion and lack of recognition were encountered at levels considered critical. This demonstrates the need to further examine the expression of these factors in the organization of the work process, considering that they pose serious risks to the physical and mental health of the workers and can lead to the acquisition of some diseases ${ }^{(1-3,13-15)}$.

Regarding the factors that generate experiences of feelings of pleasure in the work, identification with the tasks performed and professional achievement were found at satisfactory levels for both the nurses and the nursing technicians. This is because the act of caring for others who are fragile and dependent, normally makes it possible for the nursing staff to have experiences of very pleasant feelings, above all that of being useful, which consequently gives them a sense of developing socially noble work ${ }^{(1-2)}$. It should be noted that the results also confirmed that the actions involved in the process of care for the seriously ill person, due to the variability, along with the complexity, require workers to go beyond what is prescribed, allowing them large spaces for acting in a more personal way or with a unique style, providing a singular meaning; therefore presenting itself as a channel through which the professionals can express themselves, pursue and achieve their desires, wishes and possibilities(10-11). Furthermore, in most cases, the nurses and the nursing technicians felt privileged to work in a sector considered one of the most important of the hospital, to be specialized and to use advanced technological resources to treat patients on the threshold between life and death. This usually gives them a status that generates feelings of pride, satisfaction, well-being and pleasure(1-2), however, these feelings were not perceived in this study.

Despite the positive factors present in the work process, it was found that there were signs of intense exhaustion, slightly higher in the nurses who occupy hierarchically superior positions to the nursing technicians, certainly from assuming for themselves a high degree of responsibility in the provision of care to the critical patient. The nursing technicians expressed that the distress is greater at the beginning than the end of the career, possibly because at first they found themselves pressured to learn to cope with complex tasks performed on humans beings at risk of imminent death and that over time they adapt to the distress provoked by the work they perform. The physical 
distress in the ICU is usually intense, caused mainly by the efforts expended to achieve the diverse care for the patients who are bedridden, which causes various types of pain, especially in the legs, the lumbar region and the back $^{(16-19)}$. The mental distress originates from the frequent interruptions due to the unexpected and from dealing with suffering and death ${ }^{(1-2)}$. Death in the ICU has the connotation that there was inefficiency of the team, and therefore, that all the work was lost. The feelings generated by the loss of patients are extremely difficult to elaborate, because they cause much anguish, however they cannot be freely expressed in the work context ${ }^{(1-2)}$. Suffering in the work also comes from the contact with the family members of patients who tend to project feelings of depression and anxiety, caused by hospitalization, onto the nursing staff, especially in times of tension, with the worsening of the clinical framework or death ${ }^{(1-2)}$. Given the above, it appears that the forms of management and organization of the work in the ICU should especially allow workers spaces for expression of their various feelings arising from the task of caring, which are difficult to elaborate, in order to reduce the distress $^{(1-2)}$. In this sense, a satisfactory evaluation was observed in this study in relation to the factor freedom of expression, which remains for the nursing technicians at the beginning and end of their careers, but increases towards the end for the nurses. It was inferred that greater familiarity with the work process increases the security, creativity and ability to cope with teams/ groups, essential for the nurse who is the coordinator of the team.

The results showed that there was solidarity and freedom to talk about the work with colleagues, aspects of extreme importance in the ICU, which dispense with spontaneous help to ensure accuracy, speed and promptness in the attendance. However, the factors "freedom to speak openly at work" and "trust in colleagues" were found at levels considered critical, which demonstrates the need to strengthen the construction of collective work, going beyond the concept of teamwork, in the majority of cases comprehended as something stable, inspired by the principles of Taylorism. Collective work is constructed daily by the subjects involved in it who, from the representation of the activity, negotiate their commitments, whether implicit or explicit, for the articulation of different actions by the different workers ${ }^{(10-}$ $11,20)$. The cooperation between the workers becomes motivated by the pursuit of quality, an essential condition for obtaining pleasure in the work. To this end, a flexible management model is necessary to allow the experience of the feeling of recognition from the hierarchy and the peers, which occurs when the organization emphasizes the independence of the employees in an internal structure that allows negotiation in the definition of hierarchical roles, in the standards and the rules(12-13,15). As a result this brings the possibility of a psycho-affective structuring of the socio-professional relationships, necessary for the strengthening of the identity through the construction of the collective work ${ }^{(12-13,15)}$.

To operate with managerial flexibility, power must not derive from the position at work, but from the specialization, the knowledge, and the personal relationships. It is therefore crucial to foster a form of collective work which promotes articulation of the actions and integration of the individuals. The search for consensus of the team based on communicative practice, i.e. on the communication oriented towards understanding, permits the construction of a project of common assistance most appropriate to the health needs of the patients ${ }^{(20)}$. Thus, it was found that both the nurses and the nursing technicians expressed that the factor recognition, composed of feelings of indignation, injustice and devalorization, was at critical levels. These feelings are probably related to the lack of working conditions they are exposed to in the public hospitals, such as the lack of human resources, equipment and materials, which generates an overload for the workers and a lack of care for the patients ${ }^{(6,13)}$.

Studies show that the indignation of the ICU nursing team may have other motives and is manifested individually or collectively, due to the lack of humanization in the patient care: disregard for the body after death, care in calling the patient by name, treating them by the bed number, and categorizing the patient by the procedure performed, among others ${ }^{(21)}$. The feeling of injustice in the ICUs is usually related to lack of valorization of the nursing professionals, who are the ones taking care of the patients all the time, but are not recognized by the patients nor by the institution(1-2). Low wages are also considered one of the factors that characterize the devalorization of nursing, imposing on the workers the need for double shifts, which motivates absenteeism due to health problems(22). It appeared that the nurses and the nursing technicians, to withstand the pressures and psychological suffering originating from the adverse working conditions, may develop individual and collective defensive strategies, such as distancing, denial and depersonalization. These defensivestrategies negatively affect psychic functioning, changing their 
forms of existence. Moreover, the trivialization and the denial of the suffering can lead to the crystallization of individual and collective defensive strategies, making them rigid workers who are resistant to changes.

\section{Conclusion}

One of the limitations of this study is the lack of indepth comprehension of the subjective dimension of the causal factors of the suffering and pleasure in the work in the ICU nurses and nursing technicians. A second limitation is the possibility of bias in prevalence, characteristic of the cross-sectional study. It was concluded that the nurses and nursing technicians encounter, in their work in the ICU, factors that contribute to experience feelings of pleasure, above all due to the practice of care being extremely significant, and the factors related to freedom of expression in the work allowing them to exercise forms of individual and collective work satisfactorily. However, it was verified that the work causes intense emotional exhaustion, and produces feelings of dissatisfaction. The lack of recognition was seen to be significant, which is expressed by feelings of indignation and injustice. It is therefore necessary to review the work process in order to provide greater work satisfaction.

\section{References}

1. Shimizu HE, Ciampone MHT. As representações dos técnicos e auxiliares de enfermagem acerca do trabalho em equipe na unidade de terapia intensiva. Rev. LatinoAm. Enfermagem. 2003;12(4):623-30.

2. Shimizu HE, Ciampone MHT. Sofrimento e prazer no trabalho vivenciado pelas enfermeiras que trabalham em Unidades de Terapia Intensiva em um hospital escola. Rev Esc Enferm USP. 1999;33(1):95-106.

3. Van Den Touren M, De Jonge J. Managing job stress in nursing: What kind of resources do we need? J Adv Nurs. 2008;63(1):75-84.

4. Lautert L. O desgaste profissional: estudo empírico com enfermeiras que trabalham em hospitais. Rev Gaúcha Enferm. 1997;18(2):133-44.

5. Martins MCA. Situações indutoras de estresse no trabalho de enfermeiros em ambiente hospitalar. MILLENIUM - Rev Instituto Superior Politécnico de Viseu [periódico de Internet]. out 2003. [acesso 12 ago 2007]; (28). Disponível em: WWW.ipv.pt/millenium/ millenium28/18.htm.

6. Spindola T, Santos RS. Mulher e trabalho: a história de vida de mães trabalhadoras de enfermagem. Rev. Latino-Am. Enfermagem. 2003;11:593-600.
7. Dejours C. Da psicopatologia a psicodinâmica do trabalho. Rio de Janeiro: Fiocruz; 2004.

8. Dejours C. Psicodinâmica do trabalho: contribuições da escola dejouriana à análise da relação prazer, sofrimento e trabalho. São Paulo: Atlas; 1994.

9. Mendes AM. Da psicodinâmica à psicopatologia. In: Mendes AM. Psicodinâmica do trabalho: teoria, método e pesquisas. São Paulo (SP): Casa Psi; 2007. p. 29-48. 10. Schwartz Y. La conceptualisation du travail, le visible et I' invisible. L' Omme Societé. 2004;152-153:47-77.

11. Schwartz Y. Reconaissances Du travail: por une aproche ergologique. Paris: PUF; 1998.

12. Kovner C, Brewer C, Wu Y, Cheng Y, Suzuki M. Factor associated with work satisfaction of registered nurses. J Nurs Scholarship. 2006;38(1):71-9.

13. Abrahão JI, Torres CC. Entre a organização do trabalho e o sofrimento: o papel de mediação da atividade. Rev Produção. 2004;14(3):67-76.

14. Ferreira MC, Mendes AM. Inventário sobre trabalho e adoecimento - ITRA: Instrumento auxiliar de diagnóstico de indicadores críticos no trabalho. In: Mendes AM. Psicodinâmica do trabalho: teoria, método e pesquisas. São Paulo (SP): Casa Psi.; 2007. p. 111-22.

15. Mendes AM, Tamayo A. Valores organizacionais e prazer sofrimento no trabalho. Rev PSICO- USF.; 2001;6(1):39-46.

16. Kennedy BR. Stress and Burnout of nursing staff working with geriatric in long term care. J Nurs Scholarship. 2005;37(4):381-82.

17. Marziale MHP, Carvalho EC de. Condições ergonômicas do trabalho da equipe de enfermagem em unidade de internação de cardiologia. Rev. Latino-Am. Enfermagem. 1998;6 (1):99-117.

18. Marziale MHP, Robazzi MLCC. O trabalho de enfermagem e a ergonomia. Rev. Latino-Am. Enfermagem. 2000;8(6):124-7.

19. Célia RCRS, Alexandre NMC. Aspectos ergonômicos e sintomas osteomusculares em um setor de transporte de pacientes. Rev Gaúcha Enferm. 2004;25(1):33-43.

20. Peduzzi M. Equipe multiprofissional de saúde: conceito e tipologia. Rev Saúde Pública. 2001; 35(1):103-9.

21. Salicio DMB, Gaiva MAM. O significado de humanização da assistência para enfermeiros que atuam em UTI. Rev Eletronica Enferm. 2006;8(3):370-6.

22. Sentone ADD, Gonçalves AAF. Sofrimento no trabalho: significado para o auxiliar de enfermagem com dois vínculos empregatícios. Seminário Ciências Biológicas e da Saúde 2002;23(1):33-8.

Received: Sep. 22 2010 Accepted: Mar. $17^{\text {th }} 2011$ 